\title{
GUIDELINES FOR IMPROVING LOGISTIC PERFORMANCES AS DRIVERS OF THE LOGISTIC INDUSTRY DEVELOPMENT
}

\author{
Ratko Stanković, Mario Šafran, Diana Božić
}

Preliminary notes

Changes in the Croatian economy, introduced upon accession to the European Union, significantly influenced the needs for logistics services, and thus the logistic industry. In planning investments and development of their business, companies mainly rely on their own marketing activities and experience, which are of limited scope, without scientific approach and analysis. For this reason, a systematic research on the current demand for logistics services has been initiated, along with defining guidelines for improving Croatian logistics industry performance. Final conclusions are enhanced by comparative analysis of the research results and the logistic performance indicators provided by the World Bank. Guidelines for improving the logistic industry performance outlined in this paper should be considered as scientific contribution in defining national development strategy of the logistic sector.

Keywords: guidelines; improving; logistic industry; performance

Smjernice za unaprjeđenje logističkih performanci u funkciji razvoja logističke industrije

Prethodno priopćenje

Promjene u hrvatskom gospodarstvu, nastale nakon pristupanja Europskoj uniji, znatno su utjecale na potrebe za logističkim uslugama, a time i na logističku industriju. U planiranju investicija i razvoja svog poslovanja, poduzeća se uglavnom oslanjaju na vlastite marketinške aktivnosti i iskustva, koja su ograničenog dosega, bez znanstvenog pristupa i analize. Iz tog razloga, pokrenuto je sustavno istraživanje aktualne potražnje za logističkim uslugama, uz definiranje smjernica za unaprjeđenje performanci hrvatske logističke industrije. Konačni zaključci prošireni su komparativnom analizom rezultata istraživanja i pokazatelja logističkih performanci koje objavljuje Svjetska banka. Smjernice za unaprjeđenje performanci hrvatske logističke industrije prikazane u ovom radu, predstavljaju znanstveni doprinos definiranju nacionalne strategije razvoja logističkog sektora.

Ključne riječi: logistička industrija; performance; smjernice; unaprjeđenje

\section{Introduction}

Changes in the Croatian economy, introduced upon accession to the European Union, significantly influenced the demand for logistics services and thus the logistic industry, freight forwarding at the first place. As a segment of the country's logistic sector, logistic industry encompasses business activities of logistic operators (companies that provide various logistic services, such as customs brokerage, transport, warehousing, etc.), carriers, ports and other companies that provide logistic services. The other segment of the logistic sector consists of customs system and logistic infrastructure, which are subject to government policy and regulations, although employed mostly by logistic operators. Interactions of these three elements (logistic industry, logistic infrastructure and logistic industry) represent functional basis of the logistic sector as a system.

Reductions in supply chain trade barriers improve the efficiency of the movement of goods, thus recovering resources otherwise wasted. By contrast, most tariff reductions reallocate resources, capturing only the inefficiency created by the tax. Improving only two key components of trade facilitation: border administration and logistic infrastructure, would lead to an increase of some $\$ 2,6$ trillion $(4,7 \%)$ in global GDP and $\$ 1,6$ trillion $(14,5 \%)$ in global trade. The complete worldwide tariff elimination would only add a further $\$ 400$ billion $(0,7 \%)$ to global GDP, or $\$ 1,1$ trillion $(10,1 \%)$ to global trade [1].

There is a strong relationship between logistic performance and logistic costs, whereas lower logistic performance tends to have higher costs. According to perception of its logistic industry performance, Croatia is ranked between a partial performer and a consistent performer [1]. It points out Croatia still has not fully exploited the potentials of its geographical position and logistic infrastructure, which should have been recognised upon accession to the European Union. It is crucial to define portfolio structure and development perspectives of the logistic industry, as it generates value out of investments and efforts made in improving customs system and logistic infrastructure.

In planning investments and development of their business, companies mainly rely on their own marketing activities and experience, which are of limited scope, without scientific approach and analysis. For this reason, a systematic research of the current demand for logistics services has been initiated, along with guidelines and projections of further development of the logistics industry in Croatia. The research was carried out within the project Analysis of Logistics Services in the Republic of Croatia with Guidelines for Cooperation with the Economy [2], approved and financed by the University of Zagreb. Input data for the research (facts, knowledge and attitudes regarding the logistic needs of the Croatian economy) were collected by using available statistical data, case studies of particular logistic solutions and online survey which included the relevant users of logistics services. Preliminary results of the research were presented at the International Conference on Industrial Logistic, ICIL 2014, Bol, Croatia [3] while the final conclusions are outlined in this paper.

The most important issues covered by the research outlined in this paper can be summarized as follows:

- Analysing current structure of the logistic demand in the Croatian economy;

- Formulating projections of further development of the logistics industry in Croatia; 
- Defining guidelines for further improvement of Croatian logistic industry performance;

- Creating a database of information and knowledge needed for improvement of curricula and conducting further research in this area.

Final conclusions set forth in this paper are enhanced by comparative analysis of the research results and the logistic performance indicators provided by the World Bank.

\section{Main aspects of European integrations affecting the logistic industry in Croatia}

Improving logistics performance is at the core of the economic growth and competitiveness agenda. Supply chain reliability is a major concern for traders and logistic operators alike. In a global environment, consignees require more certainty about when and how deliveries will take place. This increases the demand for quality in logistics services, posing challenges both for logistic operators and for governments. It is still too early for ultimate conclusions regarding the effects to the logistic services demand of the Croatian economy, since Croatia has joined the EU only a year ago. However, some preliminary assessments should be made, in order to facilitate planning of logistic infrastructure development and further research on logistic industry development trends. Such assessments could be based on the results of the research outlined in this paper and on the available statistical data and relevant experience from the neighbouring countries, Slovenia at the first place. In this respect, the most important aspects of European integrations affecting the logistic industry in Croatia could be summarized as follows:

- Customs borders with neighbouring EU countries have been eliminated, while Croatian border against Serbia, $\mathrm{BiH}$ and Monte Negro has become a part of the customs border of the EU;

- $\quad$ Port of Rijeka has become an EU port, i.e. an entry point to the European market;

- Croatia has become a convenient transhipment station for European distribution networks in supplying markets of former Yugoslavian countries.

- Geographical position of Croatia has gained major importance not only for transit corridors towards the Central European Countries, but also to Baltic (Route 65 ) and to the rest of former Yugoslavian countries.

In order to analyse the new situation on the market and outline prospective changes in the structure of logistic services demand, the authors have carried out an inquiry among relevant logistic operators and users of logistic services in Croatia. The information acquired refers to actual traffic in the period from the beginning of July 2013 till the end of March 2014 and to the expectations of the examinees. The main issues to be taken in consideration are outlined in the following paragraphs.

\subsection{Logistic infrastructure}

Business expansion on the single European market, with respective increase in the volume of trade flows, provides new opportunities for planning, development and implementation of intermodal transport, which is a standard in developed economies [4], as well as setting up modern customs terminals and cross docking centres at suitable points of transport routes.

By integration into the single EU market, the Port of Rijeka becomes an EU port and the logistics infrastructure in Croatia is gaining importance. Also the market positions previously acquired by global logistic operators will be strengthened up, which will result in further attracting of transit cargo flows. Hence, the need for further development of Croatian section of TransEuropean Transport Network occurs (Fig. 1), as well as setting up a modern logistics centre\& customs terminal in continental Croatia, which could also act as a background terminal of the Port of Rijeka [4].

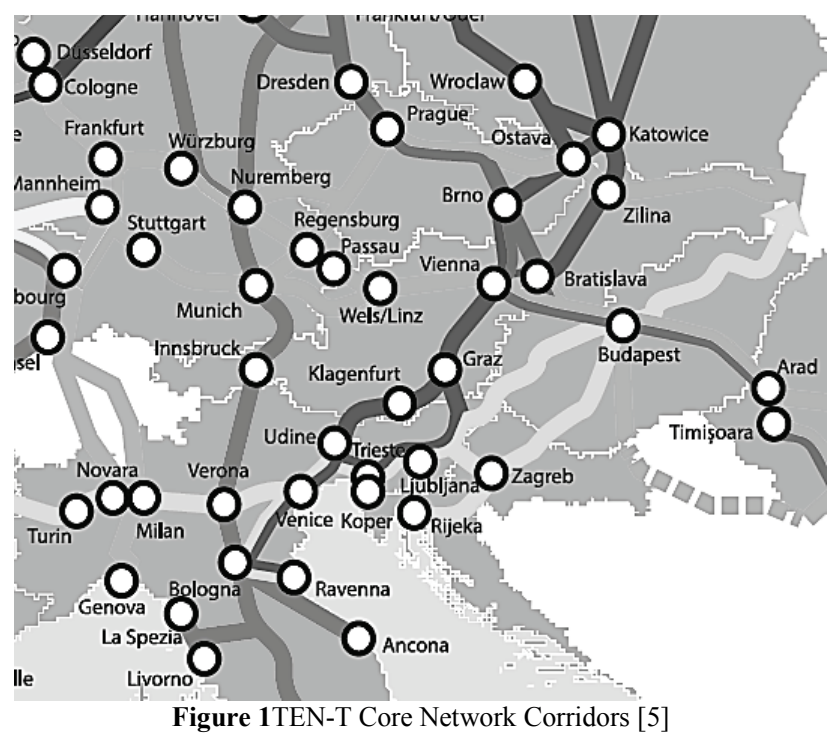

\subsection{Customs operations}

The first visible impact of accession to the EU refers to elimination of customs borders against the neighbouring European countries, while the Croatian borders against third countries became borders of the EU. It resulted in decrease in number of customs operations, which is expected to correspond with the fact that more than $60 \%$ of Croatian foreign trade refers to the EU countries [4]. Also the customs procedures have been greatly simplified by implementing NCTS (New Computerized Transit System), AIS (Automated Import System) and ECS (Export Control System).

Total number of customs declarations related to import and export has not been significantly decreased immediately upon the accession due to the transport \& customs procedures started before 1st of July 2013, which therefore needed to be finalized according to the old regulations. At first, it caused traffic jams at the borders against third countries and at the customs terminals, as most of the freight forwarders had already cut down the staff or closed some of their offices. Also the new customs software needed some time to adopt. The situation began to normalize by the end of July 2013. Significant decrease of the number of customs declarations was registered in August and has remained on that level. 
Since Croatia holds the part of EU border on its territory, customs operations in transit (NCTS) over Croatia are to be done at Croatian part of EU border. Also the customs clearance of goods at import from third countries and export to third countries, for any EU country can be done in Croatia. It makes a great difference for international road transport at the first place, but also for combined transport (air - road and sea - road). Major routes of international road transport across Croatian territory are depicted in Fig. 2.

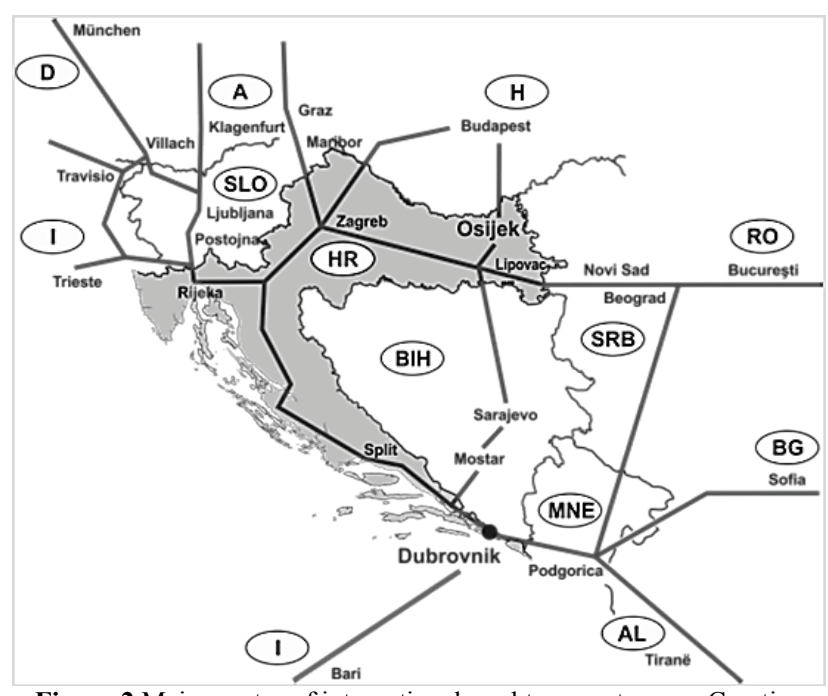

Figure 2 Major routes of international road transport across Croatian territory [6]

The Croatian economy should benefit from these changes, however the opportunities greatly depend on the available logistic infrastructure and effectiveness of the Croatian customs and logistic operators who are expected to speed up the customs procedures.

\subsection{Distribution networks}

For similar reasons as with the customs operations, distribution centres with customs warehouses have remained busy in the first part of July 2013, but with negative trend started in August. Operations in nonbonded warehouses and local delivery/collection operations have remained at the same level.

Customs warehouses are no longer needed for transhipment of goods originated from or destined to EU countries, so the transhipment operations are shifted to non-bonded warehouses. However, there are significant trade flows between the EU and third countries, which could be a substratum for stronger involvement of Croatian logistic infrastructure (ports and inland cargo centres at the first place) into the European distribution networks. It refers mainly to the Port of Rijeka, which has become an entry point to the European market and to a prospective new cargo centre near Zagreb [7].

\subsection{Intrastat reporting}

While the customs procedures in trade with the EU countries were eliminated, another way of control has been implemented. Every entering or arrival of goods from one member country to another or every leaving or dispatch of goods from one member country to another is being reported to Intrastat, a system of collecting statistics on the trade in goods between the member countries of the EU. Intrastat form is a statistical report that contains less data than a customs declaration and is issued on monthly basis (up to the $15^{\text {th }}$ for the previous month).

Every company included in the VAT system, whose value of trade in goods with the member countries exceeds the exemption threshold, either for dispatches or arrivals, or for both trade flows, is obliged to declare Intrastat data. Many companies have not been included in the system due to relatively high threshold value $(1,7$ million $\mathrm{kn}$ ), which was determined based on the simulation data [8] shown in Tab. 1.

Table 1 Simulation of the Intrastat coverage based on data from 2012

\begin{tabular}{|l|c|c|c|}
\hline & Total & Export & Import \\
\hline $\begin{array}{l}\text { Companies involved in } \\
\text { foreign trade with EU }\end{array}$ & 22788 & 6945 & 20991 \\
\hline $\begin{array}{l}\text { Companies included in } \\
\text { Intrastat system }\end{array}$ & 4289 & 1240 & 3779 \\
\hline $\begin{array}{l}\text { Percentage share in total } \\
\text { number of companies, \% }\end{array}$ & 18,8 & 17,9 & 18,0 \\
\hline $\begin{array}{l}\text { Percentage share in total } \\
\text { value of trade, \% }\end{array}$ & - & 97,0 & 95,0 \\
\hline
\end{tabular}

The threshold value has been decreased to 1,2 million $\mathrm{kn}$ for the period of 2014, which makes more companies included. Intrastat data can also be utilized by the companies that provide the data, in analysis and planning of production, purchasing and sales, market research and making strategic business decisions.

\section{Research plan}

The research plan involves four steps [2], needed to obtain scientificaly relevant conclusions:

1) Collecting data, knowledge and attitudes regarding logistic needs of the Croatian economy by using available statistical data and implementation of survey among users of logistics services.

2) Processing the information collected in the previous step, in order to define actual structure of the logistic services demand and formulate projections of the logistic industry development.

3) Comparative analysis of the second step results and the LPI scoring (cf. infra, Chapter 3.2) of Croatian logistic sector.

4) Determining final conclusions and guidelines for conducting further research.

The research plan was initialy set within the time frame of six months, but needed to be extended for one more month due to the survey completion.

\subsection{Development of the survey}

The survey was performed on a sample of the first 1000 firms in Croatia, ranked by the annual sales in international trade. The companies with insignificant logistic needs were excluded that way and the criterion was implemented based on the data provided by the Croatian Financial Agency (FINA) and the Croatian Bureau of Statistics. 
In order to obtain a suitable data base structure, the survey questionnaire was designed to cover the following groups of information:

1) Company profile (categorical data, classifying subjects in predefined classes against the number of employees, core business, market scope) information needed for segmentation and categorization of the respondents. The user interface (window) provided predefined answers/options, a responded was asked to select from.

2) Current logistic needs (activities/services, volumes, service quality) - information needed for assessment of actual logistic needs of the Croatian economy. The user interface for data input consisted of several windows, each dedicated to a particular set of data. The respondents were asked either to select a predefined answer/option on an ordinal scale for categorical data (respective service quality) or to enter numerical data (number of customs declarations/TEUs/trucks/wagons/shipments/tons, depending on the logistic service involved).

3) Current logistic solutions and level of satisfaction - information needed for assessment of current potential of the logistic market. The input data are categorical (predefined answers/options), related to the implemented logistic solution (internal resources/outsourcing/partial outsourcing) and related to the level of satisfaction with the implemented solution (completely satisfactory/partly satisfactory). Several user interface windows were provided for the data input, each one referring to the respective logistic activity, such as customs clearance, intrastate reporting, different modes of transport, warehouse operations, etc.

4) Prospective logistic needs and desirable solutions - information needed for forecasting and determining development trends of the logistic industry. The input data are categorical, with predefined options for selecting logistic services and respective expectations (increase/decrease/unchanged), which were entered via several user interface windows.

The survey questionnaire consists of 79 questions in total, but not each one must be answered, as particular answers exclude/include certain groups of questions. The questionnaire form is too big to be enclosed to the paper, however the results are discussed in Chapter 4.

The software used to design the questionnaire and carry out the survey was Lime Survey, an open source online survey application written in PHP (Hypertext Preprocessor - a server-side scripting language designed for web development) based on SQL (Structured Query Language) database and hosted by the University Computing Centre (SRCE). It enables automated sending of invitations, reminders and tokens by email, as well as exporting data in various formats: text, CSV (Comma Separated Value), PDF (Portable Document Format), SPSS (Statistical Package for Social Studies), R (programming language for statistics), queXML (questionnaire toolkit, Extensible Markup Language) and Microsoft Excel, which was essential for realization of the survey.
Although a number of routines for basic statistical and graphical analysis are available within the Lime Survey, the survey data were exported in Excel format, in order to utilize some more advanced features included in the Excel Analysis ToolPak. Selected results of the survey data processing (only the most relevant for this paper) are discussed in Chapter 4

\subsection{Logistic Performance Index (LPI)}

The international Logistic Performance Index (LPI) is a summary indicator of a country logistic sector performance, combining data on six core performance components into a single aggregate measure, developed by the World Bank. The six core components are:

1. The efficiency of customs and border clearance;

2. The quality of trade and transport infrastructure;

3. The ease of arranging competitively priced shipments;

4. The competence and quality of logistics services;

5. The ability to track and trace consignments;

6. The frequency with which shipments reach consignees within scheduled or expected delivery times.

The LPI report has been issued biannually since 2007. relying on a structured online survey of logistics professionals from the companies responsible for moving goods around the world: multinational freight forwarders and the main express carriers, those best able to assess how countries perform. And their views matter, directly affecting the choice of shipping routes and gateways and influencing firms' decisions on production location, choice of suppliers, and selection of target markets. Nearly 1000 logistics professionals based in 125 countries took part in the 2013 survey for the 2014 LPI which included 166 countries [1].

Each survey respondent rates on a scale from "very low" (1) to "very high" (5) eight overseas markets on six core components of logistics performance. The eight countries are chosen based on the most important export and import markets of the country where the respondent is located, on random selection, and for landlocked countries on neighboring countries that form part of the land bridge connecting them with international markets.

\section{Discussion of the results}

In order to get a representative survey sample, various companies were included, from micro enterprises to big enterprises, food and non-food sector, in production and commerce business. The response rate was $19 \%$ of the survey sample (1.000 companies in total were contacted). The conclusions regarding current and prospective structure of the logistic services demand were mainly based on analysis of current logistic solutions implemented by the respondents and respective level of satisfaction, prospective logistic needs of the respondents, desirable logistic solutions and scale of logistic services employed. 


\subsection{Analysis of the survey results}

Segmentation of the survey sample (companies that responded to the survey) is defined according to company profile. Implemented criteria and respective percentage share are listed below:

1) Criterion: Core business

- Production: $45 \%$

- Commerce: $55 \%$

Sub criteria: Food/Non-Food, Wholesale/Retail/Both

2) Criterion: Number of employees

- $\quad$ Micro Enterprise; up to 10 employees: $7 \%$

- $\quad$ Small Enterprise; 11 to 50 employees: $31 \%$

- Middle Enterprise; 51 to 250 employees: $29 \%$

- $\quad$ Big Enterprise; 251 and more employees: 33 \%.

Current logistic needs, logistic solutions implemented and respective level of satisfaction were analyzed for the following logistic operations, as well as prospective logistic needs in the following two years period indicated by the examinees:

- Customs clearance;

- Intrastat reporting;

- $\quad$ Maritime transport (FCL/LCL separately);

- Waterway transport (containerized/non-containerized cargo separately);

- Air freight;

- Rail transport;

- Road transport (international/local and FTL/LTL separately);

- Courier service (international/local and docs/packages/pallets separately);

- Warehousing (bonded/non-bonded, warehouse space and basic operations/VAS separately).

Depicting full-scale results would exceed the work frame of this paper, so only the most relevant results are sorted out to outline the outcomes of the survey data analysis. Charts shown in Fig. 3, Fig. 4 and Fig. 5 are developed by the authors, based on the data derived from the survey.

\subsubsection{Logistic solutions}

Percentage share of a particular logistic solution in cases where different solutions were implemented are outlined in Fig. 3. Other logistic activities (maritime transport, air freight, rail transport, courier services) were $100 \%$ outsourced, except of waterway transport which was not employed at all.

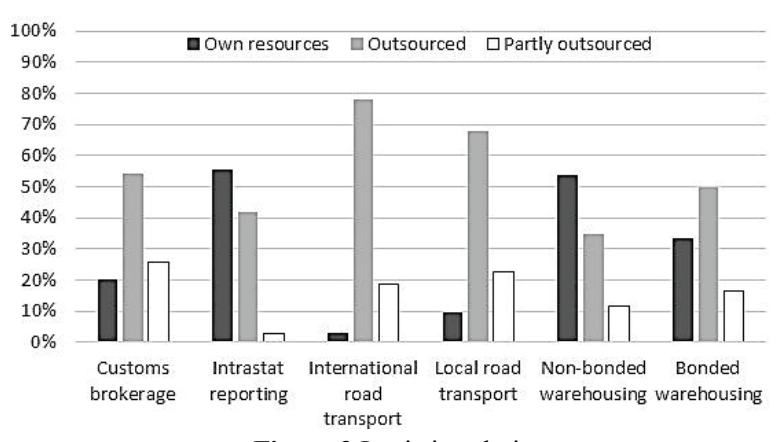

Figure 3 Logistic solutions
Percentage share of a particular logistic solution indicates maturity of the market, where average share of logistic outsourcing (fully and partly) is $71 \%$. Road transport is the most outsourced (over $90 \%$ ), while intrastat reporting and warehousing are less than $50 \%$ outsourced.

It points out which segments of the market are not saturated, thus being a potential for stronger involvement of the logistic industry.

\subsubsection{Logistic services quality}

The respondents' perception of the logistic services quality provided by carriers and logistic operators is outlined in Fig. 4. No assessment was made on waterway transport, as it was not employed by any respondent.

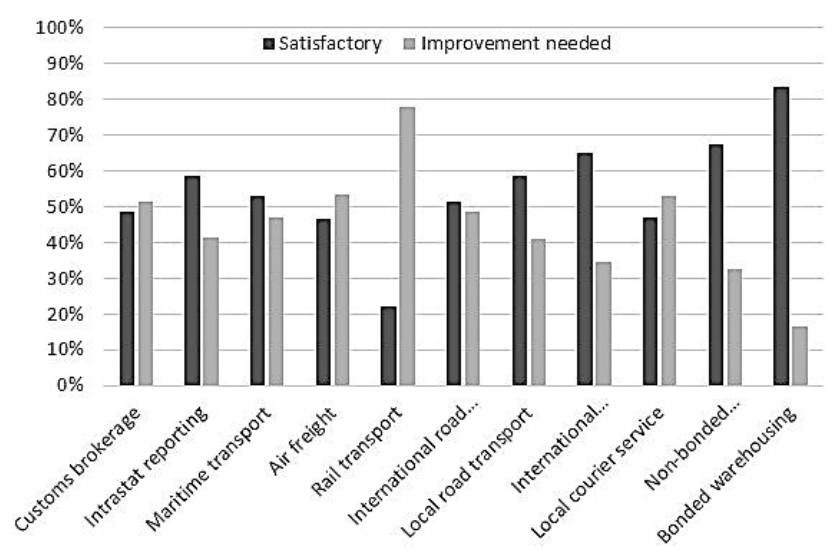

Figure 4 Quality of the logistic services provided

Logistic services quality perceived by the users, depicts the profile of the logistic industry performance. Average perception of the logistic services quality is satisfactory to $55 \%$ of the respondents. Quality of warehousing services and Intrastat reporting is perceived satisfactory by more than average percentage of respondents. Referring to the previous paragraph, it shows the quality of the services is acceptable, but available capacities are insufficient.

Rail transport inspires general dissatisfaction, being ranked the lowest (78\% dissatisfied), followed by airfreight (53\% dissatisfied) and customs brokerage (51 $\%$ dissatisfied). Each performance of these services highly depends on public logistic infrastructure and government regulations, pointing at the public sector weakness.

\subsubsection{Tendencies of needs for logistic services}

The respondents' expectations regarding tendencies of needs for logistic services in the next two years period, expressed as percentage share of a particular expectation frequency (increase/decrease/unchanged), regarding a particular logistic service, are outlined in Fig. 5.

Average $60 \%$ of the respondents expect logistic needs to remain unchanged, average $31 \%$ expect increase, and average $9 \%$ expect decrease. Demand is expected to increase more than average for Intrastat reporting at the first place, followed by airfreight and road transport services. The lowest percentage of respondents expect increase of demand for rail transport service (13\%), 
which is equal to the percentage of those who expect the demand to decrease.

Regarding Intrastat reporting, the results correspond to the lowering of the threshold value to 1,2 million $\mathrm{kn}$ for the period of 2014, which makes Intrastat reporting obligatory for a greater number of companies.

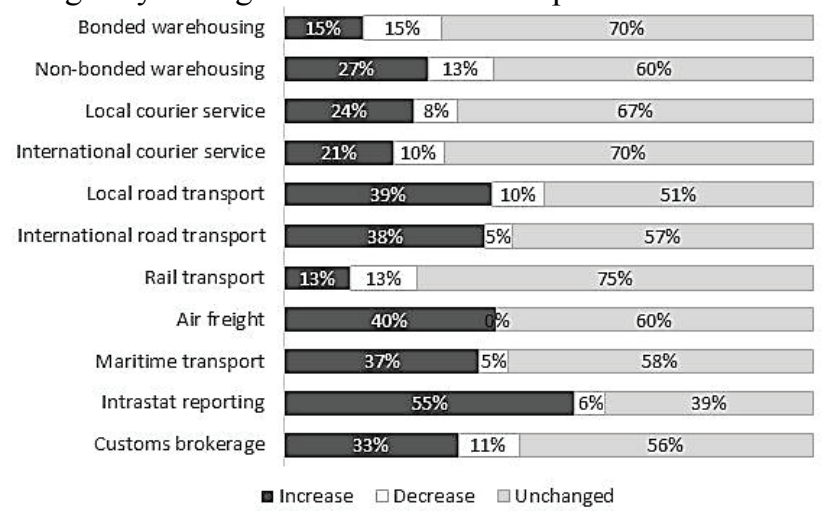

Figure 5 Expected tendencies of needs for the logistic services

Air freight becomes more competitive with lower freight rates introduced by logistic operators and air cargo agents, while road transport remains the dominant mode of surface transport, partly due to a poor performance of rail transport.

\subsection{Croatian logistic sector LPI}

In aggregated 2007-14 LPI, Germany ranked highest at 4.10 LPI, and all the EU member states were among the top third countries, the lowest being Croatia ranking $55^{\text {th }}$ at 3.02 LPI $(65,3 \%$ of the top score) [1].

For the purpose of identifying segments of the Croatian logistic sector where improvements are most needed, the LPI scoring of each performance component needs to be analyzed separately, as well as its impact to the overall LPI scoring. Croatian LPI scoring of each performance component in the period from 2007 to 2014 is shown in Fig. 6, while the same period aggregated LPI scoring is shown in Fig. 7. Charts shown in Figure 6 and in Fig. 7 are developed by the authors, based on the data derived from the World Bank LPI Report [1].

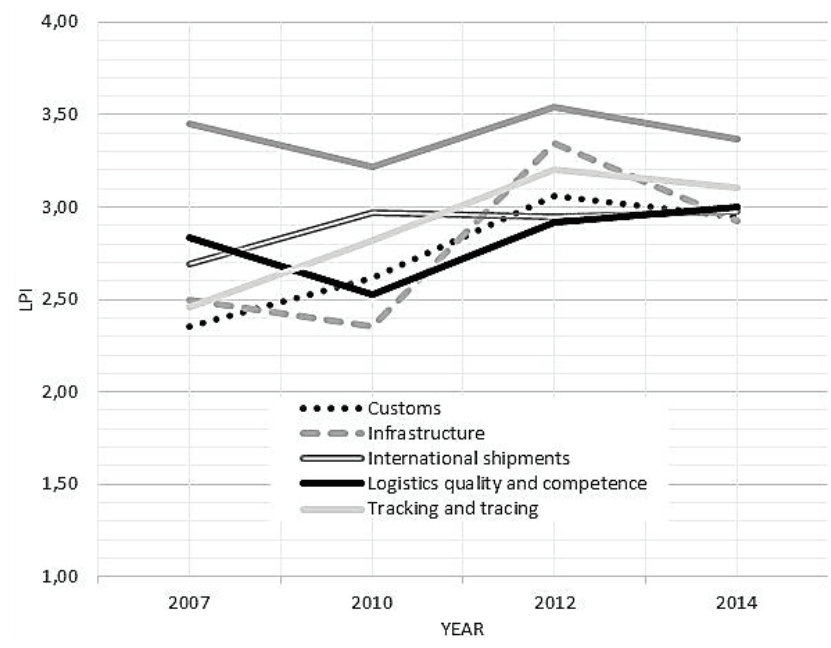

Figure 6 LPI scoring of each performance component in the period from 2007 to 2014
In each year (Fig. 7), the timeliness dimension is notably stronger than the others, though the LPI is based on a survey among logistic operators (freight forwarders in particular) and might skew this slightly toward the positive. However, timeliness is the highest ranking component across the entire period, and logistic quality and competence is the only component ranking higher in the period after than in the period prior to the accession to the EU. Both components are directly related to the logistic operators' performance, which is constrained by available logistic infrastructure and respective legal frame (efficiency of customs procedures at the first place).

Fig. 6 shows which of the six components of the international LPI are above the overall index and which are below, as a preliminary indication of areas of relative strength and weakness in the Croatian logistic sector. The logistic industry performance (the top four components) compensates for weakness of the public domain (customs system and logistic infrastructure).

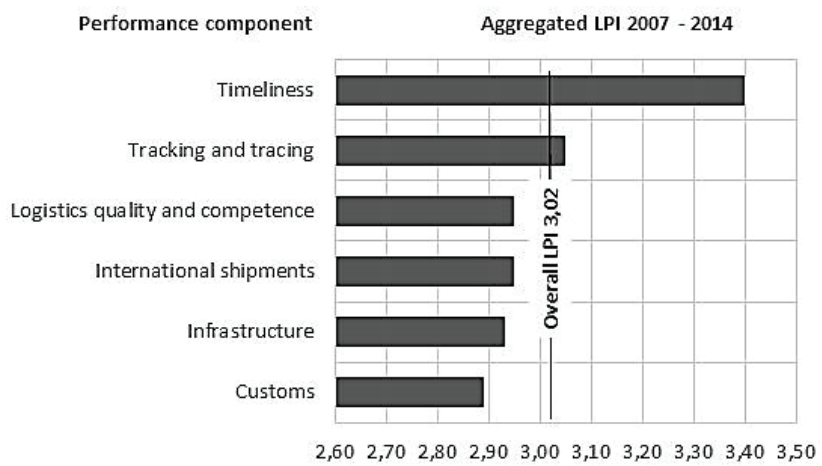

Figure 7 Aggregated LPI scoring of each performance component

Logistic infrastructure and customs system are the main points of negative performance, which make logistic services more expensive and difficult to arrange.

\subsection{Comparing findings of the survey results analysis and the LPI scoring}

The results of the survey data analysis indicate potential of the Croatian logistic market, profile of the logistic industry performance and segments of the logistic sector where improvements are most needed. They correspond with the results of the LPI scoring in pointing at the weakness of the public segment of the Croatian logistic sector.

The most obvious is the lack of reliable rail services, which is considered as an option only by fewer number of transport users. While green transport policies emphasize the importance of modal shift from roads to rail, influencing the demand for rail beyond captive bulk markets, a respective transformational change in performance is not happening.

Efficient border management is critical for eliminating avoidable delays and enhancing predictability in boarder clearance. Besides geography and speed en route, another factor in import lead times is the efficiency of customs process at the border. Even as customs procedure becomes gradually more similar (since the accession to the EU), it still remains a constraint in international trade flows. 
Performance of the logistic service providers is perceived better than the quality of the corresponding infrastructure they operate. It points out the need for improving logistic infrastructure, in order to facilitate competitiveness and further development of the Croatian logistic industry.

\section{Conclusion}

Results of the research primarily reflect the recent changes in the structure of logistic services demand in the Croatian economy. Users of logistic services tend not to fully define logistic solutions, but to extensively exploit the know-how and resources of logistic operators.

Logistic operators are expected to participate in defining supply chain strategy and to provide for optimal logistic solution, which emphasises their managerial competences. It makes logistic operators responsible not only for performance of the services, but for the outcome of implemented logistic solution.

Integration into the single European market yields new development prospective for the Croatian logistic industry, however the logistic infrastructure and efficiency of the customs system still remain the constraints. Further research should be focused to enhancements in these segments, in order to enable exploiting advantages of the geographical position and facilitate the logistic industry competitiveness.

Investments and efforts made in improving customs system and logistic infrastructure are utilized by the logistic industry, therefore they act as drivers of the logistic industry development. Guidelines for improving the logistic sector performances outlined in this paper, should be considered as academic contribution in defining national development strategy of the logistic industry.

\section{References}

[1] Connecting to Compete 2014: Trade Logistics in the Global Economy, The International Bank for Reconstruction and Development/The World Bank, Washington DC, 2014.

[2] Project No. 5.4.2.1, Analysis of Logistics Services in the Republic of Croatia with Guidelines for Cooperation with the Economy, University of Zagreb, Zagreb, 2013 - 2014.

[3] Stanković, R.; Šafran, M.; Hrupački, S. Structure of Logistic Services Demand in Croatian Economy. // Proceedings of the International Conference on Industrial Logistics, Bol, 2014.

[4] Stanković, R.; Šafran, M.; Kristijan R. Development perspectives of the logistic industry in Croatia upon accession to the European Union. // Proceedings of the 1st Logistics international conference, Beograd, 2013.

[5] Trans-European Transport Network, URL: http://ec.europa.eu/transport/index en.htm, (02.04.2015)

[6] Operational Programe Transport 2007 - 2013, Ministry of Maritime Affairs, Transport and Infrastructure, Zagreb, 2013.

[7] Feasibility study Cargo center Zagreb, Department of Transport logistic, Faculty of transport and traffic sciences, Zagreb, 2012.

[8] Croatian Bureau of Statistics, Zagreb, 2012.

\section{Authors' addresses}

Ratko Stanković, Asst. Prof., Ph.D.

University of Zagreb, Faculty of Transport and Traffic Sciences, University Campus, Borongajska cesta 83a, HR-10000 Zagreb E-mail: ratko.stankovic@fpz.hr

Mario Šafran, Prof., Ph.D.

University of Zagreb, Faculty of Transport and Traffic Sciences, University Campus, Borongajska cesta 83a, HR-10000 Zagreb E-mail: mario.safran@fpz.hr

Diana Božić, Ph.D.

University of Zagreb, Faculty of Transport and Traffic Sciences, University Campus, Borongajska cesta 83a, HR-10000 Zagreb E-mail: diana.bozic@fpz.hr 